\title{
Integrating Multimedia Technology into Teaching Chinese as a Foreign Language: A Field Study on Perspectives of Teachers in Northern California
}

\author{
Siyi Gao \\ Chinese Language Department, Asian School One, Defense Language Institute Foreign Language Center, USA
}

\begin{abstract}
This field study investigated the current use of multimedia technology in teaching Chinese as a foreign language in Northern California, as well as the barriers and challenges that TCFL teachers have encountered in their practice. An online survey was developed to collect data from 75 local TCFL teachers in Northern California. Findings indicated that most teachers felt they were competent enough in using multimedia technology. About half of the TCFL teachers had never received formal training on multimedia skills, even though they did not view a lack of training opportunities as a major barrier to multimedia use. The lack of school funding was the most critical factor in hindering teachers' use of multimedia. The study argues for the need to provide more support to TCFL teachers at the institutional level. More training programs are also needed to prepare teachers for a shift of role from traditional sources of knowledge to facilitators of technology-mediated learning.
\end{abstract}

Index Terms - Teaching Chinese as a Foreign Language, multimedia

\section{INTRODUCTION}

The teaching of Chinese as a foreign language (TCFL) in the U.S. has become the chicken or the egg problem: many schools are reluctant to provide Chinese programs because qualified teachers are not available in their regions; institutions of higher education are reluctant to offer teacher education programs because prospective teachers are inadequate; while the field of TCFL is not attractive to prospective teachers unless adequate resources are in place.

Added to the teacher shortage problem is the shift in the role of teachers in the twenty-first century from traditional sources of knowledge to facilitators of learning. In the context of TCFL, not only should qualified teachers be proficient in the language and be skillful in pedagogy and communication, but they should also be technology literate and facilitators of learning using new technologies or more effective use of existing technologies. This requires experienced teachers who were used to traditional classroom instruction to realize the potential for improving learning through effective use of technology, and the need to become competent or even proficient technology users.

Among the challenges local TCFL teachers face, incorporating multimedia into their lessons ranks at the top of the list. In this era of digital technology, they believe that using technology effectively in the classroom will greatly benefit learners. Despite a wide array of research that have been conducted to investigate the effectiveness of integrating multimedia technology into TCFL, a dearth of research is available on TCFL teachers' perspectives on multimedia use. As teachers are at the forefront helping students acquire language skills, their accounts on the current multimedia environment, levels of self-confidence and feelings of efficacy, as well as factors contributing to their use or lack of use of multimedia are valuable inputs to determining ways to elevate multimedia integration into teaching.

Against this background, the present field study addresses the following questions:

1. What is the current environment of multimedia technology in Northern California Chinese language classrooms?

2. What types of multimedia do TCFL teachers use to serve certain language domains?

3. How do TCFL teachers perceive their competencies in integrating multimedia into TCFL, as well as the training opportunities available to them?

4. How do TCFL teachers prepare multimedia-based materials for class?

5. What factors influence TCFL teachers to use multimedia technology in their teaching?

6. What are the challenges and barriers TCFL teachers perceive when integrating multimedia into their teaching?

\section{LITERATURE REVIEW}

Research on how Chinese language instructors today incorporate multimedia in their teaching is an important area of study because there is currently not much related research in the U.S. To conduct this research, this literature review 
covers related studies in the following areas: (1) current practice of multimodal use in education; (2) integrating multimedia into foreign language teaching; (3) integrating multimedia into teaching Chinese as a foreign language; (4) value and effectiveness of integrating multimedia into teaching; (5) barriers teachers face when integrating multimedia into teaching; and (6) critiques of teachers on integrating multimedia into teaching.

\section{A. Current Practices of Multimedia in Education}

As multimedia has become more useful and normalized in daily life, its uses in education has increased in various countries through multiple methods and formats. Support for using multimedia in education comes not only from schools, educators, parents, and students, but also from governments.

A U.S. survey study from the Bill \& Melinda Gates Foundation (2012) noted that 67 percent of 400 teachers from across the 50 states use technology in every class and 85 percent use it every day. Despite high utilization of technology by teachers, most teachers remain skeptical that "there is little, widely accepted proof that technology tools provide real value for student learning." To encourage schools and educators to use multimedia in education, the government also has established some policies to promote the use of multimedia in the classroom. The National Center for Education Statistics has figures showing that in 2008, 31 percent of public schools reported that there were full-time staff in the school whose sole responsibility was technology support or technology integration. In addition, 47 percent of secondary schools reported having such staff compared with 27 percent of elementary schools (Gray, Thomas \& Lewis, 2010a). There are also statistics showing that in 2009, almost all public school teachers had instructional computers with Internet access available to them in the classroom, and half of the teachers could bring computers into the classroom. Almost all these instructional computers had wireless network access in the classroom (Gray, Thomas \& Lewis, 2010b).

At the state level, policies have been in place to solve the problem of limitations in public school access to a wireless network (WiFi). Per the California Department of Education, there are two programs that offer discounts to California public schools for the purchase of telecommunications, Internet access, and computer hardware. The first program, Erate, is a federal program that offers eligible K-12 public schools as much as a 90 percent discount on approved technology. The California Teleconnect Fund (CTF) is a state program that offers discounts for Internet bandwidth and other technology-related services. California provides incentives for successful technology integration into schools.

In China, the Chinese Ministry of Education embarked on a new education policy in the early 1990s emphasizing networked education, with the goal of connecting every school to the Internet and integrating computers into school curricula (Fang \& Warschauer, 2004). Since then educational units nationwide have responded to the policy. For example, in 2000, the China Education and Research Network (CERNET) reached a major milestone by linking every university in China to the Internet. Along with the national CERNET, provincial and institutional language teaching and research networks, such as the Jiangsu English Language Teaching and Research Network (JSELTRNET), also helped to develop telecommunication networks in higher education (Foster and Goodman, 2000). By 2001, China had already integrated 3 million computers and 150,000 computerized classrooms into nearly 100,000 elementary and secondary schools, benefiting more than 50 million students (Fang \& Warschauer, 2004). In 2010, the Ministry of Education (MOE) issued its National Long-Term Education Reform and Development Plan (2010-2020) to embark on a series of education reforms in China for the coming decade. Part of this ten-year plan is devoted to accelerating educational informatization by speeding up information infrastructure construction, developing and applying more quality education resources, and building a state education information management system. In the same year, the MOE outlined a highlevel vision for a revolutionary transformation in education. They called for leveraging technology to measure, diagnose, and modify learning conditions and instructional practices to build the capacity of educators - teachers, parents, experts, and mentors outside the classroom, improve student learning outcomes, and manage costs (Chen, 2014).

\section{B. Integrating Multimedia into Foreign Language Teaching}

Given the worldwide importance of the language, English as a second language (ESL) has long been a prevalent subject in many countries. There have been large numbers of research studies on pedagogies and tools to improve the quality of ESL teaching. As technology has begun to play a critical role in the twenty-first century, integrating multimedia into ESL learning has become a prevalent research topic worldwide.

Yeh and Wang (2003), for example, compared the effect of auditory and visual stimuli in computer-assisted English vocabulary acquisition by Chinese speakers. The study found that visual stimuli are more effective than auditory stimuli. After this, Al-Seghayer (2001) investigated which of the image modalities - dynamic video or still picture - is more effective in aiding vocabulary acquisition. Thirty ESL students at the University of Pittsburg were measured under three conditions: text definition alone, text definition with still pictures, and text definition with video clips. Results suggested that a video clip in combination with text definition was most effective in teaching unknown vocabulary. Video clips and text were linked together in meaningful ways to provide participants an in-depth experience and mental image, and help them learn and recall more words than still pictures and text. At the same time, related research done in Taiwan investigated the relationship between learners' perceptual learning styles and the effectiveness of various types of vocabulary annotations on vocabulary learning - text only, text plus picture, and text plus picture and sound. This study of 82 ESL students at the National Tsing Hua University in Taiwan showed that text plus pictures was the most effective of the three types, and perceptual learning style was not a significant factor to the effectiveness of vocabulary annotations (Yeh \& Wang, 2003). 
Similar research studies have also been done for learning German as a second language. For instance, one study examined the effectiveness of annotations with multimedia applications to vocabulary learning. This study was conducted with 160 university German language students using a hypermedia application. Findings showed that text plus pictures was more effective in learning words than text plus video or text only (Chun \& Plass, 1996). Another study examined the effectiveness of three types of glosses on German learning: text-only, picture-only, and text-andpicture (Kost, Foss \& Lenzini, 1999). This study of university students from a second-semester German class showed that text-and-picture gloss was the most effective of the three gloss types. The study also suggested that learners' preferred learning styles should be further explored so that the design of vocabulary annotation could better facilitate customization of course materials.

For Spanish as a second language learning, Rubin (1990) discovered that video played an important role in enhancing the listening skills of language learners. Results of the study showed that upper-introductory level Spanish students who watched dramas on video improved in listening comprehension compared to students who received no video support. The studies described above generally suggested that visual and sound were more beneficial than text only in learning foreign language.

Other studies related to using multimedia to increase learning results and communication skills also showed significant positive findings. Some studies were conducted to compare ESL with other foreign languages. For example, Clarke and Heaney (2003) studied the use of asynchronous computer conferencing to support the teaching and learning of English literacy with ten to eleven-year-old ESL students from schools in Northern Ireland and the Republic of Ireland. The study suggested in quality terms that valuable understandings and literary skills can be developed in this way. In Turkey, a study investigated the impact of the use of multimedia with a textbook to teach English as a foreign language on teachers' instructional practices. Subjects were 14 English teachers at a state university in Turkey teaching Turkish-speaking college students. The focal point of the project was to enhance students' communicative competence and autonomy via the implementation of technological tools. The study found that teachers became more engaged in preparing supplementary materials by exploiting the new technological facilities that the new project made available for their use. The study also found that teachers were more interested in meetings and discussions with other teachers to share ideas and reflect on their own practices (Timucin, 2006).

Other studies compared classrooms of two different languages regarding multimedia integration. Ismail, Almekhlafi and Al-Mekhlafy (2010) examined teachers' perceptions about integrating instructional technology into both Arabic and English as second language classes in K-12 schools in the United Arab Emirates. A questionnaire and a focus group interview were conducted with 621 Arabic and English teachers from 67 schools. Results indicated that teachers had high perceptions of competency in technology integration. They agreed that technology enhanced students' independence, involvement, and interaction, but had mixed feelings toward the effect on developing language skills; they regarded technology as essential to promote and review teaching and learning. They also noted that using videotapes in teaching was significantly higher among Arabic teachers than among English as a foreign language teachers. Arabic teachers specified that they video-taped students while they were in action doing different tasks such as participating in a dialogue or reporting a group's answer. The purpose of such activity is to provide students with a valuable opportunity to view themselves in action and reflect on their own performance. This study also showed that using email, dictionaries and encyclopedias, language labs and electronic forums in teaching was significantly more effective for English teachers than for Arabic teachers. English teachers needed to provide their students with more opportunities to practice and to use the language since English is a foreign language for almost all students in the country. Although Arabic teachers appreciated the role of technology in promoting teaching and learning, they mainly used computers to help them prepare their instruction materials.

\section{Integrating Multimedia into TCFL}

The number of students enrolled in Chinese classes has seen substantial increases every year in recent decades. Draper and Hicks (2002) found that in 2000, approximately 24,000 students of grades 7 to 12 nationwide were studying Chinese. Furman, Goldberg, and Lusin (2009) found that in 2009, at the higher education level, there were 60,976 students learning Chinese, 18-percent increase over 2006 after 51-percent increase from 2002 to 2006. Asia Society and China Institute (2009) reported that the number of students studying Chinese in the U.S. at was modest - accounting for only four percent of foreign language enrollments in higher education, but found a major attitudinal shift was taking place. The American Council on the Teaching of Foreign Languages (2012a) found that the number of students studying Chinese in K-12 public schools in 2007-2008 was 59,860, tripled from the 2004-2005 level. As more Chinese language teachers are needed, there should be more research on teaching pedagogies as well as integrating multimedia into Chinese language study in the U.S.

As discussed in the previous section, a study on learning German as a second language showed that text plus pictures was more effective in learning words than text plus video or text only. In learning Chinese grammar, however, the findings might be different. Williams (2013) examined the effectiveness of three types of Chinese grammar teaching materials: text-only, text-picture, and text-video. The study was conducted among 53 beginning and intermediate-level Chinese language students at a public university in Massachusetts by means of immediate and delayed tests. Results showed that text-video has a significant positive effect on Chinese grammar comprehension in general. Text-video has an immediate performance improvement over text-only, but has no significant improvement in the long run. Results 
also showed that text-video is more effective than text-picture in Chinese grammar comprehension when the target form becomes more complex.

Although an increasing number of students are learning Chinese in the U.S., and teachers generally agree that multimedia use can make language learning more effective, the ways that Chinese language teachers should use multimedia to teach have rarely been investigated. This is a key issue in teaching Chinese as a foreign language in the United States. This study aims to investigate how Chinese as a foreign language instructors use multimedia in U.S. classrooms.

\section{Values of Multimedia Integration into Teaching}

As multimedia use in teaching becomes more prevalent, it is worthwhile to ask: are multimedia technology utilized in teaching simply because the technology exist, have been developed, and are widely used in other industries? Is it because we must imitate pop culture to keep the students' interest, or will doing so actually enhance student learning and teaching quality? What are the reasons teachers should consider as they decide to integrate multimedia into classes? What are the actual values of integrating multimedia into teaching?

First, previous studies have shown that multimedia and technology cannot only engage students in class but also help develop students' creative and thinking ability. In the Bill \& Melinda Gates Foundation (2012) report, teachers believed that thoughtful design, together with required professional development, was essential if emerging technologies were going to make a difference in students' lives. In an interview, a fourth-grade teacher in Wallingford, PA, commented based on her experience that educational video games and digital presentations could promote more dynamic and flexible teaching styles and engage students on their terms (Richtel, 2012). Some Taiwanese studies also present similar rationales. For example, ChanLin, Hong, Horng, Chang, and Chu (2006) collected interview data from eight Taiwanese primary and secondary school teachers who won creative teaching awards in 2002. The study investigated how computer technology was integrated into their curriculum and what factors contributed to the use of such technology. The study found that teachers used technology to prepare tests, activities, and handouts because they wanted their teaching to be diverse and creative. The teachers also employed self-monitoring instruments to encourage students to develop more creative efforts. The researchers categorized factors that influence teachers' use of computer technology in the classroom into four dimensions: multimedia access environment, personal reasons, social support, and curricular standards. The award-winning teachers in Taiwan reflected that computer technology was just one creative teaching strategy, and that teachers should integrate technology into their curriculum in ways that develop students' curiosity and thinking ability.

Previous studies have discovered the value of PowerPoint presentations for instruction. The study of award-winning teachers in Taiwan found that PowerPoint was the most frequently used multimedia tool (ChanLin et al., 2006). Several studies in the late 1990s indicated that college students found PowerPoint-based lectures more interesting than traditional lectures (Harknett \& Cobane, 1997; Lowry, 1999). Lowry reported that students taught in PowerPoint-based lectures scored higher on tests than those taught in traditional lectures (52 percent versus 44 percent). Corbiel (2007) stated that language teachers increasingly used PowerPoint presentations for teaching grammar. Color coding, bolding, font manipulation, underlining, animation schemes, and custom animation served to make grammatical rules more salient. The researcher also showed that students reacted more positively to class materials in a PowerPoint format and considered it to be a more effective learning tool than textbooks.

\section{E. Challenges of Multimedia Integration into Teaching}

The main challenges presented in previous studies were generally based on the following aspects: lack of time, lack of professional training programs, lack of equipment, lack of funding, lack of suitable instructional software, and lack of personal comfort level. Al-Senaidi, Lin and Poirot (2009) investigated perceived barriers to adopting information and communication technologies in higher education in the Sultanate of Oman, an Arab state. The study of 100 faculty members found that two major hurdles in adopting technology were lack of institutional support and lack of time, while lack of equipment, skepticism regarding ICT benefits, and lack of confidence were not major impediments.

According to a survey study by The National Center for Education Statistics on the status of education technology in U.S. public schools in 2008, 42 percent of respondents from district, school, and teacher levels felt that teachers were not sufficiently trained to integrate technology into classroom instruction; 58 percent of respondents felt that funding for education technology was inadequate, though 83 percent felt the current funding for educational technology was spent in the most appropriate ways. Some respondents also felt the need for districts to employ an individual responsible for educational technology leadership full time (51 percent) or part time (32 percent) (Gray, Thomas \& Lewis, 2010a).

Without appropriate institutionalized training for teachers in using technology, some studies reported that teachers found it difficult to realize the true value and effectiveness of integrating multimedia into teaching. To understand how K-12 educators use technology in schools, Project Tomorrow (2014) conducted its annual Speak Up Survey in 2013 among over 333,000 students, teachers, and administrators from over 9,000 schools. The study found that all teachers put "how to differentiate instruction using technology" at the top of their professional development wish-lists. In addition, the Bill \& Melinda Gates Foundation (2012) reported that teachers said access to computers, personal comfort level, and time for planning are the three biggest barriers to using technology in class. Union and school rules are the least important barriers to using technology. 
Similar challenges were found in the international setting. Yang and Huang (2008) argued that although ESL teachers in Taiwan believed that students might benefit from the utilization of technology in instruction, they faced barriers that made integration difficult to implement. These teachers highlighted barriers such as lack of appropriate training workshops, lack of personal guidance and consultancy, lack of suitable instructional software and hardware and time constraints.

\section{F. Critiques of Teachers in Multimedia Use}

It is also important to review research from the teachers' perspective. Even though there are many advantages in using multimedia in teaching, some articles consider disadvantages such as wasting time, distracting students' attention, and other problems. Bungum (2006) reported that teachers placed a high value on the products made by the students when they use technology. But the researcher also expressed concerns about the overreliance of teachers on a heavily technology instructional method which was time-consuming and neglected salient elements specified in the formal curriculum. He found that most teachers who participated in the study decided to allow students to spend the necessary time to make quality products. In the studies by Common Sense Media (2012) and Pew Research Center (2012), it was noted there is a widespread perception among U.S. teachers that students' constant use of digital technology is hampering their attention spans and ability to persevere when facing challenging tasks. Although the studies represented only the subjective views of teachers and should not be definitive proof that widespread use of computers, phones, and video games in education affects students' ability to focus, the fact that they teachers observe students for long hours every day makes the findings significant. Common Sense Media (2012), a nonprofit organization in San Francisco, reported that teachers described what might be called a "wikipedia problem", in which students have grown so accustomed to getting quick answers with a few keystrokes that they were more likely to give up when an easy answer eluded them.

Moreover, some researchers found that using too much multimedia in teaching may make students grow tired of it. McKinnon, Nolan, and Sinclair (2000) noted the continuous overuse of technology might result in students developing a less positive attitude toward it. The study of 415 secondary students in New Zealand found that students' motivation toward technology dropped once the use of the computer became part of the daily classroom instructional routine. Richtel (2012) also found that teachers often felt they had to work harder to capture and hold students' attention. He interviewed an English teacher at Troy High School in Fullerton, California, who was worried that technology was causing a deeper shift in how students learned, and, based on the proposition that the era of constant entertainment might end one day, also wondered if teachers were adding to the problem by adjusting lessons to accommodate the shorter attention spans.

Furthermore, some articles revealed that some multimedia tools have an adverse effect on both teaching and learning. Common Sense Media (2012) surveyed 685 K-12 teachers in the U.S. concerning how they think entertainment media affected students' academic and social development and found that 71 percent of teachers considered entertainment media to be detrimental for developing writing skills. In addition, Salem (2013) assessed how instant and text messaging applications such as Blackberry text messages (BBM) and WhatsApp affect the way Arabic-speaking students from Kuwait learn English as a second language. The study of 211 primary and secondary school students found that the use of instant and text messaging shortcuts and abbreviations has an adverse impact on developing vocabulary, spelling and grammar skills. This was supported in articles by Aziz, Shamim, and Avais (2013) and Rankin (2010), who studied the same problem and agreed with Salem's findings.

In addition, it has been conceded that teachers should pay attention to the most effective methods to make multimedia a more helpful teaching tool. Canning-Wilson and Wallace (2000) suggested that teachers using videos for listening comprehension in a foreign language classroom should present them in segments as opposed to presenting them as a whole. Students being exposed to constant visual stimuli might easily be distracted from the auditory component, making the learning process ineffective. Thus, although video was a popular tool among students, language teachers should be clear about the educational purpose that video served in the classroom before using it. Therefore, it was not only important for teachers to learn how to integrate multimedia into teaching, but also essential that they investigate how to use it efficiently.

\section{METHODOLOGY}

The purpose of this study is to produce an overall picture of the current environment of multimedia technology in Northern California Chinese language classrooms, to look at TCFL teachers' use of multimedia in their classroom practices, and to consider the factors that affect decisions regarding the use of multimedia in their teaching. The following sections describe the context of the study and the methods used in the questionnaire survey and the case studies.

\section{A. Survey Setting and Procedures}

The study is designed on a quantitative survey basis. Surveys, typically in the form of questionnaires, are one of the most commonly used approaches of collecting data on attitudes and perceptions from a large pool of participants. Surveys allow researchers to gather information that participants can report about themselves, such as their beliefs and 
motivations (Mackey \& Gass, 2005). An online survey was designed for Northern California Chinese Language teachers to fill out through the university's Qualtrics Survey Tool ${ }^{1}$. The topic of the survey is Survey for Northern California Chinese Language Teachers Incorporating Multimedia into Teaching Chinese. A total of 250 teachers in Northern California were contacted via email on June 22, 2014, using the Confucius Institute database of 215 teachers of Chinese as a foreign language at public or private K-16 or adult schools. We supplemented the Confucius Institute list of teachers with 35 participating teachers at the 2014 Summer Institute for Chinese Language Teachers at San Francisco State University ${ }^{2}$. The link to the online survey was sent, and teachers had one week to complete and submit the survey online.

\section{B. Participants}

After three email requests and a few individual phone calls extending across the seven-day period, a total of 75 TCFL teachers completed and submitted the survey (a return rate of 30 percent). The participating teachers included 57 females and 18 males. Sixty percent of the participants were above 40 years old. Mandarin and Cantonese were the native language of most teachers. Teachers differed in terms of years of teaching experience, student grades, students' language level, and language program. The sample was determined to be representative of the TCFL teachers in Northern California.

\section{Instrumentation}

The instrument used in this study was a questionnaire-based survey. The theoretical foundations of the study were established based on the current perspectives and trends of multimedia use in foreign language teaching. After setting the theoretical framework of the study, interviews were conducted with three TCFL teachers of local schools to specify the layout and content of the questionnaire. Afterwards, the survey was drafted based on theoretical perspectives and advices based on feedback received from a panel of six professors and experts in education, TCFL and ESL teaching.

The survey contained 29 questions that were designed in two parts. The first part of the questionnaire contained 14 multiple choice questions that collect basic background information from the participating teachers. The second part consisted of 12 multiple choice questions and three open-ended questions about four themes: frequency of use, availability of multimedia technology, preparation and training opportunities, and barriers in multimedia use. In particular, one question provided a scale table which asked how frequently teachers used various ICT and multimedia tools (from "never" to "always"). Another question contained a table asking teachers which ICT and multimedia tools were used to serve differing language domains in a Chinese language classroom. The three open-ended questions attempted to provide participants a chance to elaborate on their answers to previous questions in their own words.

\section{RESUlTS AND ANALYSIS}

Study results are organized and discussed around the following themes: (1) frequency of multimedia use; (2) availability and accessibility; (3) teachers' preparation and training; and (4) barriers to technology use.

\section{A. Frequency of Multimedia Use}

Teaching the Chinese language involves exposing students to a variety of language domains that make up language learning, including pronunciation, vocabulary, grammar, listening, speaking, comprehension, writing, Chinese characters, as well as the culture of the population that primarily speak the language. Table 1 presents, of all multimedia tools that were reported to be primarily used in a Chinese language classroom for a language domain, the percent that each multimedia tool was the primary tool used. Videos and audios were primarily used in developing pronunciation and listening skills. PowerPoint and images were primarily used in teaching vocabulary, grammar, and Chinese characters. Animation was more likely to be primarily used in introducing Chinese culture and developing listening skills.

\footnotetext{
${ }^{1}$ San Francisco State University's Qualtrics Survey Software is a web-based survey tool for creating and conducting online surveys. All survey data collected using Qualtrics surveys follow the university's Confidential Data Policy.

${ }^{2}$ The 2014 Summer Institute for Chinese Language Teachers was held from June 15 to 21, 2014. A total of 35 local teachers participated in the seven-day integrated training curriculum at San Francisco State University.
} 
TABLE 1

PERCENT OF A MULTIMEDIA TOOL REPORTED TO BE PRIMARILY USED FOR A LANGUAGE DOMAIN

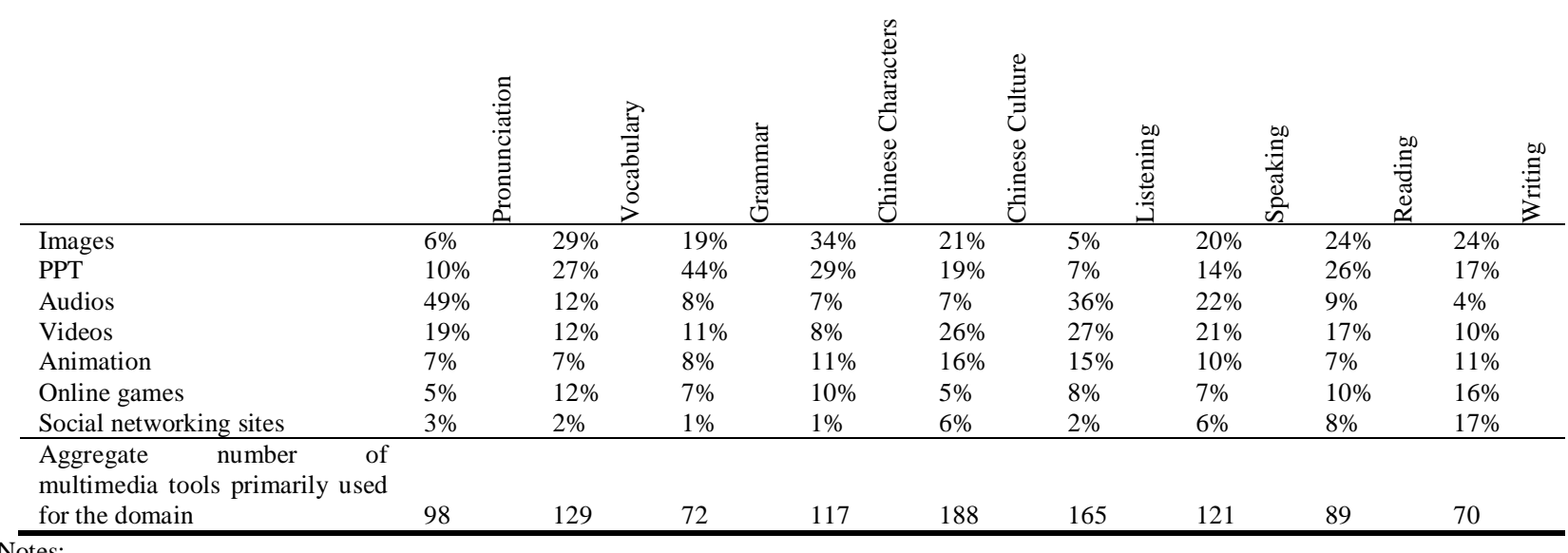
Notes:

Results were based on responses to Question 17 on the survey;

For each language domain, teachers who responded that they did not primarily use a multimedia tool for such domain were excluded respectively from the analysis of the domain presented in this table;

Since teachers were allowed to select multiple primary multimedia tools to serve for each language domain, the percentages presented in this analysis were based on the aggregate number of tools reported to be primarily used for the domain. For instance, teachers reported they primarily used a total of 98 tools when teaching pronunciation; forty-nine percent of the 98 tools were audios.

\section{B. Availability of Multimedia Technology in Chinese Language Classrooms}

In order for TCFL teachers to integrate multimedia technology into their curriculum, the technology must be available and accessible to them. The rationale behind increasing the availability of ICT in a Chinese language classroom is based on the assumption that their availability will increase teachers' use of multimedia tools, and subsequently lead to effective teaching and positive learning outcomes.

Table 2 shows the percent of TCFL teachers who reported having computers, the Internet or SMART boards in the classrooms. Results indicate that computers and the Internet were reportedly available and accessible to about three in four Chinese language classrooms. Sixty-three percent cited having projectors in their classrooms, and 28 percent reported having SMART boards in their classrooms.

TCFL teachers' availability and accessibility to these ICT varied by class characteristics, including student grade, program type, and instructional level. For example, college, high school and adult school teachers were in general more likely to have computers, the Internet, and projectors in their classrooms than junior high school, elementary school and kindergarten teachers. The availability of SMART boards in a Chinese language classroom did not significantly differ by student grade (between 24 percent and 33 percent).

There were also differences in the availability of ICT among program types. Teachers from regular language classes and Chinese immersion programs were more likely to have computers, the Internet, and projectors in their classrooms than those from after school programs, weekend Chinese schools, and private classes. Regular language classes were less likely, however, to have SMART boards in the classrooms than after-school programs, private classes, and Chinese immersion programs ( 30 percent compared with 35 percent, 40 percent, and 50 percent).

The availability of ICT in classrooms also varied by instructional level. Teachers in advanced level classes were more likely to report having more computers ( 80 percent), the Internet ( 90 percent), and social projectors (70 percent) than those in beginning level and intermediate level classes. The availability of SMART boards in a Chinese language classroom did not, however, significantly vary by instructional level (between 25 percent and 29 percent). 
TABLE 2

PERCENT OF TCFL TEACHERS REPORTING AVAILABILITy OF AND ACCESSIBILITY To INFORMATION AND COMMUNICATION TECHNOLOGIES In THE CLASSROOM

\begin{tabular}{|c|c|c|c|c|}
\hline Class characteristics & Computers & The Internet & Projectors & $\begin{array}{l}\text { SMART } \\
\text { boards }\end{array}$ \\
\hline All classrooms & $73 \%$ & $72 \%$ & $63 \%$ & $28 \%$ \\
\hline \multicolumn{5}{|l|}{ Student grade } \\
\hline $\mathrm{K}$ to 2 & $63 \%$ & $54 \%$ & $50 \%$ & $29 \%$ \\
\hline 3 to 5 & $68 \%$ & $60 \%$ & $44 \%$ & $24 \%$ \\
\hline 6 to 8 & $67 \%$ & $67 \%$ & $52 \%$ & $29 \%$ \\
\hline 9 to 12 & $80 \%$ & $90 \%$ & $67 \%$ & $33 \%$ \\
\hline 13 to 16 & $81 \%$ & $81 \%$ & $81 \%$ & $25 \%$ \\
\hline Adult school & $71 \%$ & $71 \%$ & $57 \%$ & $29 \%$ \\
\hline \multicolumn{5}{|l|}{ Program type } \\
\hline Regular language classes & $84 \%$ & $92 \%$ & $70 \%$ & $30 \%$ \\
\hline After school program & $71 \%$ & $47 \%$ & $35 \%$ & $35 \%$ \\
\hline Weekend Chinese school & $42 \%$ & $47 \%$ & $58 \%$ & $21 \%$ \\
\hline Private classes & $67 \%$ & $73 \%$ & $47 \%$ & $40 \%$ \\
\hline Chinese immersion program & $83 \%$ & $100 \%$ & $100 \%$ & $50 \%$ \\
\hline Other & $75 \%$ & $75 \%$ & $88 \%$ & $25 \%$ \\
\hline \multicolumn{5}{|l|}{ Instructional level } \\
\hline Beginning level & $71 \%$ & $75 \%$ & $59 \%$ & $29 \%$ \\
\hline Intermediate level & $75 \%$ & $75 \%$ & $59 \%$ & $27 \%$ \\
\hline Advanced level & $80 \%$ & $90 \%$ & $70 \%$ & $25 \%$ \\
\hline
\end{tabular}

Notes:

Results were based on cross tabulations between Question 18 and questions on class characteristics on the survey: Question 13 (student grade), Question 12 (program type) and Question 14 (instructional level);

Teachers making multiple selections on the student grade, program type and instructional level of their classes were included in the analyses of the respective selections;

Computers include iPads and tablets.

\section{Preparation and Training Opportunities}

The survey of multimedia use in TCFL instruction asked teachers a couple of questions regarding their preparation and training on the following topics: their perceptions of familiarity towards multimedia use; their preparation for class materials; the extent to which collaboration with other teachers contributed to the use of multimedia technology in teaching or their understanding of technology; and their participation in professional development purposes.

To answer Question 15 on the survey - "Which of the following information and communication technologies and multimedia tools are you familiar with?" - teachers selected multiple ICT and multimedia tools that they were familiar with using for instruction. Figure 1 shows that images, PowerPoint, audios, and videos received more than 84 percent of selections, whereas around half of the teachers reported they were familiar with using animation in class. Online games and social networking sites were the least likely for teachers to be familiar with, receiving less than 37 percent of selections. Results show that TCFL teachers regarded themselves as having the capabilities and skills to use different types of technologies in their teaching such as operating computers and the Internet, using multimedia tools such as images, PowerPoint, audios, and videos, and integrating multimedia presentations to enhance teaching and learning.

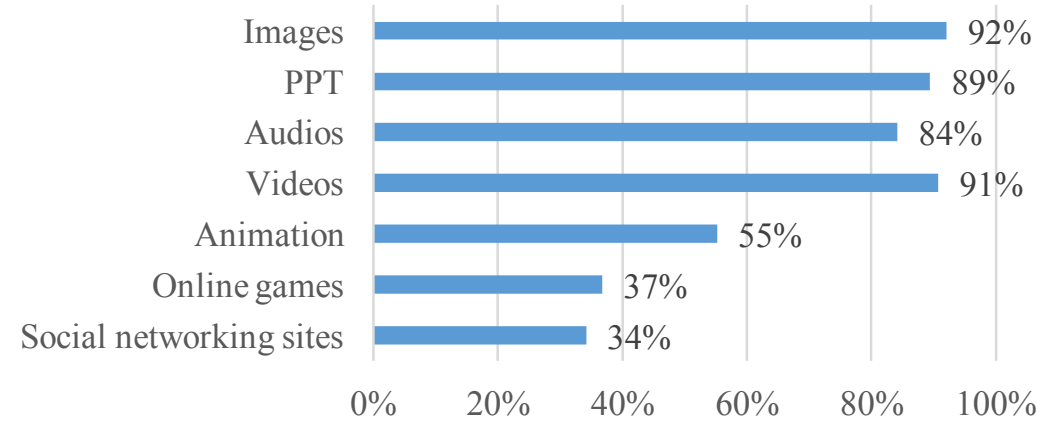

Figure 1. Percent of TCFL Teachers Reporting Being Familiar with Multimedia Tools for Instruction Notes:

Results were based on responses to Question 15 on the survey;

The number of responses available for this analysis is 75 .

The analysis of teachers' perceptions of familiarity toward ICT and multimedia tools drew comparisons with their frequency of use. This revealed that TCFL teachers integrated more multimedia technology into their classes when they 
possessed higher degree of technology self-efficacy. The finding was supported by ChanLin et al. (2006), who found that teachers that felt they had knowledge and competency in using technology for language domains more likely integrated it into the classroom.

Multimedia technologies that were of less familiarity and usage to the TCFL teachers were not necessarily a disvalue to these teachers. Though the analysis shows that many teachers perceived they did not possess the competencies to integrate SMART boards, or tools such as animation, online games and social networking sites into their classes, they admitted in their responses to Question 21 on the survey - "Which multimedia skill(s) do you need to learn or improve in the future?", that they would need to learn or improve these skills in the future. Figure 2 show that teachers were more likely to indicate the need to learn SMART board skills (25 percent) than to improve on their skills for computers and the Internet. They were also more likely to indicate the need to learn about animation (36 percent) and online games (39 percent) than to improve on their skills of the tools they were familiar with in images, PowerPoint, audios and videos. TCFL teachers generally did not view social networking sites as a tool that could benefit their teaching (13 percent).

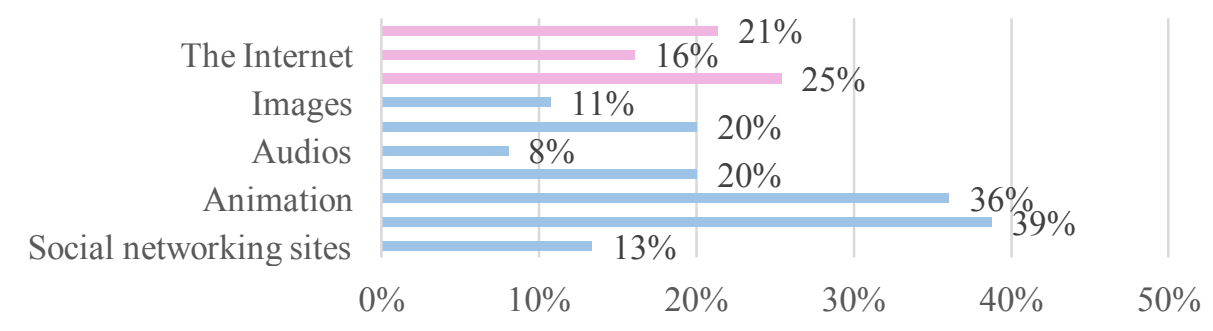

Figure 2. Percent of TCFL Teachers Reporting Need to Learn or Improve Multimedia Skills in the Future Notes:

Results were based on responses to Question 21 on the survey;

Pink bars represent ICT, while blue bars represent multimedia tools;

The number of responses available for this analysis is 75 .

\section{Teachers' Barriers to Multimedia Use}

TCFL teachers who conducted the survey were asked on whether they encountered the following barriers to their use of multimedia technology for instruction: influence from colleagues, school requirement, making teaching less effective, deficiency in student performance, lack of school funding, and contradiction to personal pedagogical approach. The section first presents information on the number of TCFL teachers who perceived these to be barriers, followed by an examination of other barriers and problems encountered by these teachers. An investigation of differences in barriers by teacher and class characteristics is the conducted. The final section explores the relationships between barriers reported by teachers and selected language domains.

Question 25 on the survey - "Which one of the following do you think most contributes to the lack of multimedia use in teaching Chinese at your school?" - attempted to collect data on teachers' perceptions of barriers to multimedia use in class through both close-ended and open-ended components. Teachers were encouraged not only to select their main barrier from a range of potential barriers but also to provide in their own words that were not best described in the choices. Of the 73 respondents, 17 of them provided their own descriptions of their major teaching barriers. Both closeended and open-ended portions of the responses were collectively used for the analysis presented in Figure 3.

The major barrier contributing to the lack of use of multimedia technology for instruction most frequently reported by TCFL teachers was lack of school funding (38 percent of teachers). In addition, 18 percent reported personal pedagogical approach, 14 percent reported school requirement, and ten percent of teachers reported outdated or unreliable computers or the Internet as their major barriers. One TCFL teacher regarded school requirement as the major impediment to his use of computers in class because he was not even allowed to use his own. The lack of institutional support as a major impediment to technology use was supported by Al-Senaidi et al. (2009) in their study of faculty members in Sultanate of Oman. 


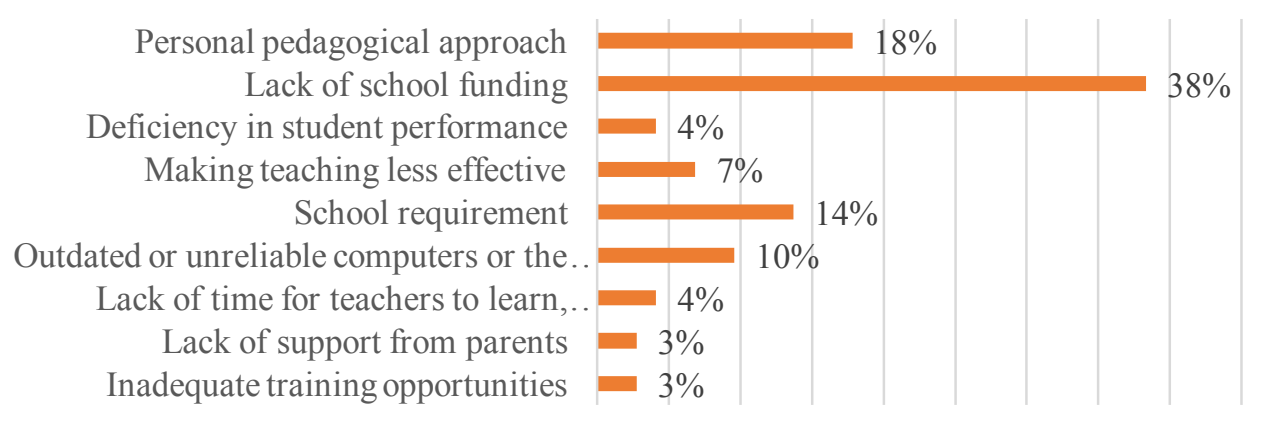

$0 \% \quad 5 \% \quad 10 \% \quad 15 \% 20 \% 25 \% 30 \% 35 \% 40 \% 45 \%$

Figure 3. Percent of TCFL Teachers Reporting their Major Barriers to Multimedia Use for Instruction Notes:

Results were based on responses to Questions 25 on the survey;

Teachers reporting "others" provided their major barrier in their own words and were compiled with other responses in this analysis; The number of respondents available for this analysis is 73 .

Furthermore, less than ten percent of teachers pointed out making teaching less effective, lack of time for teachers to learn, prepare, and implement multimedia technology for class, deficiency in student performance, inadequate training opportunities, and lack of support from parents as their major barriers. The finding that lack of time not generally viewed as the major impediments was contrary to those found in previous research (Bill \& Melinda Gates Foundation, 2012; Ismail et al., 2010; Al-Senaidi et al., 2009; ChanLin et al., 2006). An explanation to the contrary is that in these previous studies, the availability of technology resources in classes were not as much of a concern to the participating teachers as to the TCFL teachers of this study. As discussed in the earlier section, computers and the Internet were available to just under three in four Chinese language classrooms, forcing roughly one in five teachers to either bring in their own computers and the Internet or ask students to bring in theirs to classes. The finding that lack of school funding was most cited as the major barrier might help support the explanation.

Inadequate training opportunities and lack of support from parents were the least likely to be cited as their major barriers at three percent each. Despite the previous section shows that close to half of the teachers had never received training on multimedia skills and only 16 percent had received training more than two times a year, just three percent of the teachers perceived the lack of training opportunities as their major barrier. This was supported by the previous section that teachers felt they generally possessed the necessary competencies to integrate technology into their classes. Previous studies explained that, without appropriate institutionalized training for teachers in using technology, teachers found it difficult to realize the true value and effectiveness of integrating multimedia in teaching (Project Tomorrow, 2014; Bill \& Melinda Gates Foundation, 2012).

\section{DISCUSSION}

The objective of this field study was to investigate the current use of multimedia technology in teaching Chinese as a foreign language in Northern California, as well as the barriers and challenges that TCFL teachers have encountered in their practice. The literature review discusses that not only is there a shortage of TCFL teachers in Northern California, but there is also low self-efficacy among current teachers as they are preparing for a shift of role from traditional sources of knowledge to facilitators of learning using technology. Despite a wide array of research that have been conducted to investigate the effectiveness of integrating multimedia technology into TCFL, a dearth of research is available on TCFL teachers' perspectives on multimedia use.

An online survey was developed to collect data from 75 local TCFL teachers in Northern California. The survey investigated teachers' accounts on the current multimedia environment, their feelings of efficacy, as well as factors contributing to their use or lack of use of multimedia. Findings in this study indicate that most TCFL teachers in Northern California recognized the benefits of multimedia technology for themselves and for their learners. Even though ICT were available to only three in four Chinese language classrooms, most teachers who taught in those unequipped classrooms provided their own technology to their classes.

Information and communication technology and multimedia tools can be integrated into virtually any classroom situation. The key for teachers is to focus on what language domains they are trying to accomplish in the curriculum, and then to identify an appropriate combination of ICT and multimedia tools that can help them accomplish the goal. Based on the survey responses, certain tools were more likely used than others to accomplish specific language domains: TCFL teachers primarily used videos and audios in developing pronunciation and listening skills; PowerPoint and images were primarily used in teaching vocabulary, grammar, and Chinese characters; animation was primarily used in introducing Chinese culture and developing listening skills; the Internet was primarily used in introducing Chinese culture and developing reading skills; computers were primarily used for developing listening and speaking skills, as 
well as introducing vocabulary and grammar. SMART boards were primarily used in introducing Chinese culture and developing writing skills.

These patterns showed that not every language domain is best supported by every tool. No single tool can be expected to address all classroom objectives. In the context of TCFL, sorting multimedia technology by language domain is a step towards learning how to apply the right technology to a given task. By no means is the most frequently used tool necessarily the best approach for the domain; determining the best tool for a task would require empirical tests. This is also not the intent of this study to imply recommendations or endorsements for the tool for a language domain. Nonetheless, the fact that a tool was most frequently used for a language domain supported that there were benefits in using the tool and that the tool worked with many teachers.

In terms of multimedia competencies in integrating multimedia into TCFL, most teachers felt they were competent enough in using multimedia technology. TCFL teachers did not view a lack of training opportunities as their major barrier to multimedia use, but most teachers felt the need for more training opportunities, particularly the less frequently technology such as SMART boards, animation, and online games. In terms of factors hindering teachers' use of multimedia, most teachers felt that the lack of school funding was the most critical factor. It is clear that TCFL teachers were more willing to adopt multimedia in their teaching if they gained support at the institutional level.

The findings of the survey need to be considered in light of three limitations. First, the survey items were mainly drawn from empirical evidence and current trends of multimedia use in foreign language teaching, as opposed to from theoretical models. Second, the survey items regarding barriers focused on too few major categories of the reported barriers: school requirement, ineffective teaching, deficiency in student performance, personal pedagogical approach, lack of school funding, and influence from colleagues. Many subtle areas of barriers such as low feelings of efficacy, lack of time preparing, lack of technical training, and lack of access to multimedia technology were either underpresented or excluded by the participants on the survey due to their time consideration to complete the survey. Third, the sample size was too small to conduct statistical tests from the quantitative data collected via the questionnaire. Fourth, the quantitative, survey-based study suffered from a lack of qualitative understanding of the problem. A mixed method of questionnaires and focus group interviews with selected teachers could have led to better and more in-depth understanding of the problem. Overall, findings from this study were limited. It is recommended future studies validate and extend the results found in this study.

Future research can explore how to design and develop a curriculum for professional multimedia training classes for all TCFL teachers in the U.S. Another option is to investigate the efficacy of various multimedia in helping to engage students in learning the Chinese characters, or the effects of appropriate uses of images on improving students' learning. Any related research subjects can help TCFL teachers have a better idea about what multimedia skills to learn and to incorporate into their teaching.

\section{APPENDIX. SURVEY FOR NORTHERn CALIFORNIA CHINESE LANGUAGE TEACHERS INCORPORATING MUlTimEDIA IN} TEACHING CHINESE

\section{北加州地区中文教师使用多媒体教学情况调查}

Section 1: Basic Information/第一部分：基础信息

Q1. Name/姓名:

Q2. Gender/性别: oMale/男 oFemale/女

Q3. Age/年龄: $\quad \circ 20-30 \quad \circ 31-40 \quad 041-50 \quad \circ 51-60 \quad \circ 61$ and above /61 岁及以上

Q4. What is/are the name(s) of the school(s) you are currently teaching at? /您现在哪些学校任教? 请注明学校

名称:

Q5. How would you define the multimedia used in the classroom?

您是怎样定义和理解课堂教学中使用的“多媒体”的?

Q6. What is your native language? / 以下哪种语言是您的母语?

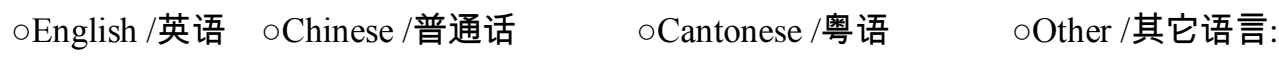

Q7. What is the highest level of degree you have achieved? /您获得的最高文凭是什么?

○High School Diploma/高中毕业文凭 oTwo-year college/专科文凭 oB.A. or B.S. /学士文凭 ○M.A. or M.S. /硕士文凭 $\quad$ Ph.D. /博士文凭

Q8. In which region did you achieve your highest level of education? /您在哪里获得您的最高文凭?

○U.S. /美国 ○China Mainland/中国大陆 ○Hong Kong/香港佂台湾

○Other country or region/其它国家或地区: 
Q9. In which field did you achieve your highest level of education?/您在哪个领域获得您的最高文凭?

○Teaching Chinese as a second language/对外汉语专业领域

○Chinese literature or linguistics / 中国文学或语言学中非对汉语专业的其它学科

○English literature or teaching English as a second language /英美文学或教授英文作为第二外语专业

○Education / 教育学领域

○Other field /其它领域:

Q10. For how long have you been a Chinese language teacher?/您做汉语教师多长时间?

○1-5 years/年 ○6-10 years/年 ○11-20 years/年 ○21-30 years/年 ○31 years and above/年及以上

Q11. Do you have a teaching credential?/您是否已考取教师资格证?

○Yes (Please select the type of teaching credential) /是 (请选择教师资格证类别)

A. Multiple Subject Teaching Credential/多科小学教师证

B. Single Subject Teaching Credential /单科中学教师证

C. California Professional Clear Single Subject in Teaching Chinese as a Foreign Language/加州单科对外汉语教师证 oNo, I don’t have a teaching credential. /不，我没有考取教师资格证

Q12. In which Chinese language program(s) are you teaching?/您在哪种中文项目中任教? (可多选)

$\square$ Regular Mandarin classes/全日制学校中文项目 $\square$ After-school program/中文课后班项目

$\square$ Weekend Chinese school/周末中文学校䟚私人课程

口Chinese immersion program/中文沉浸项目听ther program/其它项目:

Q13. To which grade(s) do you teach Chinese?/您教授哪个年级汉语 ? ( 可多选 )

$\square \mathrm{K}-2 \quad \square 3-5 \quad \square 6-8 \quad \square 9-12 \quad \square 13-16 \quad \square$ Other grade/其它年级:

Q14. What level(s) of Chinese courses do you teach?/您教授哪个级别的汉语课程 ? (可多选 ) 口Beginning level/初级汉语 $\quad \square$ Intermediate level /中级汉语 $\quad \square$ Advanced level/高级汉语

Section 2: Use of Multimedia in Chinese Teaching /第二部分：使用多媒体辅助汉语教学

Q15. Which of the following multimedia tool(s) and resource(s) are you familiar with? 以下哪些多媒体教 学工具和资源是您所熟悉的？(可多选)

$\square$ PowerPoint $\square$ Audios/音频 口Images/图像 口Videos/视频 $\square$ Animation/动画

$\square$ Online games/线上游戏 $\quad \square$ The Internet /互联网 口Computers including iPads and tablets /电脑包括平板电 脑 口SMART Boards /电子白板 口Social networking sites /社交网站

Q16. How often do you use the following multimedia tools and resources in teaching Chinese in class? (If your answer is "Never", please specify reasons.)

您在课堂教学中使用以下多媒体教学工具和资源的频率是怎样的? (请选择您认为合适的选项作为答案。如果 您的回答是 “从不”, 请注明原因 )

Definition /定义:

$\checkmark \quad$ Every time /每次

$\checkmark \quad$ Often, in about $90 \%$ of the chances I could have /很经常，频率大概为 $90 \%$

$\checkmark \quad$ Usually, in about $70 \%$ of the chances when I could have / 经常，频率大概为 $70 \%$

$\checkmark$ Sometimes, in about $50 \%$ of the chances when I could have /有时，频率大概为 $50 \%$

$\checkmark$ Occasionally, in about $30 \%$ of the chances when I could have /偶尔, 频率大概为 $30 \%$

$\checkmark \quad$ Rarely, in less than $10 \%$ of the chances when I could have /很少，频率低于 $10 \%$

$\checkmark \quad$ Never/从不 


\begin{tabular}{|c|c|c|c|c|c|c|c|}
\hline & $\begin{array}{l}\text { Every } \\
\text { time } \\
\text { 每次 }\end{array}$ & $\begin{array}{l}\text { Often } \\
\text { 很经常 }\end{array}$ & $\begin{array}{l}\text { Usually } \\
\text { 经常 }\end{array}$ & $\begin{array}{l}\text { Sometimes } \\
\text { 有时 }\end{array}$ & $\begin{array}{c}\text { Occasionally } \\
\text { 偶尔 }\end{array}$ & $\begin{array}{l}\text { Rarely } \\
\text { 很少 }\end{array}$ & $\begin{array}{c}\text { Never } \\
\text { (Reasons) } \\
\text { 从不 (原因) }\end{array}$ \\
\hline $\begin{array}{l}\text { PowerPoint / } \\
\text { 演示文稿 }\end{array}$ & & & & & & & \\
\hline Audios /音频 & & & & & & & \\
\hline Images /图像 & & & & & & & \\
\hline Videos /视频 & & & & & & & \\
\hline Animation /动画 & & & & & & & \\
\hline $\begin{array}{l}\text { Online games / } \\
\text { 线上游戏 }\end{array}$ & & & & & & & \\
\hline The Internet /互联网 & & & & & & & \\
\hline $\begin{array}{l}\text { Computers or tablets / 电 } \\
\text { 脑或平板电脑 }\end{array}$ & & & & & & & \\
\hline $\begin{array}{l}\text { SMART Boards / } \\
\text { 电子白板 }\end{array}$ & & & & & & & \\
\hline $\begin{array}{l}\text { Social networking sites / } \\
\text { 社交网站 }\end{array}$ & & & & & & & \\
\hline
\end{tabular}

Q17. In which area(s) do you primarily use each of the multimedia tools and resources in teaching Chinese in class? (Please select at most 3 areas for each tool. If your answer is "Never", please specify reasons.)

您主要在以下哪个部分中使用各种多媒体教学工具和资源进行汉语教学? (每种多媒体教学工具请限选三项。 如果您的回答是 “从不”，请注明原因 )

\begin{tabular}{|c|c|c|c|c|c|c|c|c|c|c|}
\hline & $\begin{array}{l}\text { Pronun- } \\
\text { citation } \\
\text { 语音 }\end{array}$ & $\begin{array}{l}\text { Vocab- } \\
\text { ulary } \\
\text { 词汇 }\end{array}$ & $\begin{array}{l}\text { Grammar } \\
\text { 语法 }\end{array}$ & $\begin{array}{l}\text { Chinese } \\
\text { Characters } \\
\text { 汉字 }\end{array}$ & $\begin{array}{l}\text { Culture } \\
\text { 文化 }\end{array}$ & $\begin{array}{l}\text { Listening } \\
\text { 听 }\end{array}$ & $\begin{array}{l}\text { Speaking } \\
\text { 说 }\end{array}$ & $\begin{array}{l}\text { Reading } \\
\text { 读 }\end{array}$ & $\begin{array}{l}\text { Writing } \\
\text { 写 }\end{array}$ & 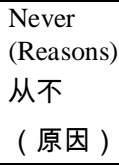 \\
\hline $\begin{array}{l}\text { PowerPoint / } \\
\text { 演示文稿 }\end{array}$ & & & & & & & & & & \\
\hline $\begin{array}{l}\text { Audios } \\
\text { 音频 }\end{array}$ & & & & & & & & & & \\
\hline $\begin{array}{l}\text { Images } \\
\text { 图像 }\end{array}$ & & & & & & & & & & \\
\hline $\begin{array}{l}\text { Videos } \\
\text { 视频 }\end{array}$ & & & & & & & & & & \\
\hline $\begin{array}{l}\text { Animation } \\
\text { 动画 }\end{array}$ & & & & & & & & & & \\
\hline $\begin{array}{l}\text { Online game } \\
\text { 线上游戏 }\end{array}$ & & & & & & & & & & \\
\hline $\begin{array}{l}\text { The Internet } \\
\text { 互联网 }\end{array}$ & & & & & & & & & & \\
\hline $\begin{array}{l}\text { Computers, } \\
\text { iPads } \\
\text { tablets / 电 } \\
\text { 或平板电脑 }\end{array}$ & & & & & & & & & & \\
\hline $\begin{array}{l}\text { SMART } \\
\text { Boards } \\
\text { 电子白板 }\end{array}$ & & & & & & & & & & \\
\hline $\begin{array}{l}\text { Social } \\
\text { networking } \\
\text { sites } \\
\text { 社交网站 }\end{array}$ & & & & & & & & & & \\
\hline
\end{tabular}

Q18. What multimedia tool(s) do you have in the classroom?/您教室中有哪些多媒体工具? (可多选)

$\square$ PowerPoint $\square$ Audios/音频 $\square$ Videos/视频 $\square$ The Internet/互联网 
$\square$ Computers, iPads and tablets /电脑或平板电脑 口SMART Boards /电子白板

$\square$ Projectors /放映机

口Not applicable /没有多媒体工具

$\square$ Other / 其它多媒体工具:

Q19. Which multimedia tool or resource do you think is the most useful in teaching Chinese? (Select one) 您认为哪种多媒体工具或资源对汉语课堂教学最有帮助? (限选一项)

$\square$ PowerPoint $\square$ Audios/音频 口Images/图像哽视频 $\square$ Animation/动画

$\square$ Online games/线上游戏 $\quad \square$ The Internet/互联网 口Computers, iPads \& tablets /电脑或平板电脑

$\square$ SMART Boards /电子白板 $\quad \square$ Social networking sites / 社交网站

$\square$ Other / 其它多媒体工具或资源:

口Not applicable / 都没帮助

Q20. Which multimedia tool or resource do you think your students like the most? (Select one)

您认为学生最喜欢您课堂教学中使用哪种多媒体工具或资源 ? (限选一项)

$\square$ PowerPoint $\square$ Audios/音频 口Images/图像 口Videos/视频 $\square$ Animation/动画

$\square$ Online games/线上游戏 $\square$ The Internet/互联网 $\square$ Computers, iPads \& tablets /电脑或平板电脑

$\square$ SMART Boards /电子白板 $\quad \square$ Social networking sites / 社交网站

$\square$ Other / 其它多媒体工具或资源:

口Not applicable /学生都不喜欢

Q21. Which multimedia skill(s) do you want to learn or improve in the future? Why?

您今后想学习或提高哪些多媒体技术? 为什么? (可多选)

$\square$ PowerPoint $\square$ Audios/音频 口Images/图像 口Videos/视频 $\square$ Animation/动画

$\square$ Online games/线上游戏听e Internet/互联网 $\square$ Computers, iPads \& tablets /电脑或平板电脑

$\square$ SMART Boards /电子白板 $\quad \square$ Social networking sites / 社交网站

$\square$ Other / 其它多媒体技术:

$\square$ Not applicable / 都没有

Reason/原因:

Q22. How do you usually prepare multimedia resources for class teaching? (Select all that apply)

您通常如何获取多媒体教学资源？(可多选）

口Do-It-Yourself /自己制作 口Downloading from the Internet/网上下载

口Borrowing from others / 借用他人资源 $\square$ Recommended by others / 他人推荐

$\square$ Other/其它方式:

Q23. Have you ever participated in any training courses on multimedia skill(s)? If yes, how often?

您是否曾参加过关于多媒体工具使用技巧的培训? 如果是, 频率是多少?

$\circ$ Yes / 是 (How often /频率:

○No, I have not participated in such training. /不, 我没有参加过这种培训。

Q24. Which of the following do you think most contributes to the availability and use of multimedia in teaching Chinese at your school? /下列哪个因素对您使用多媒体教学影响最大？(限选一项)

OSchool requirement/学校规定及要求 oMaking teaching more effective/提升教学质量

oInfluence from colleagues /同事影响 OImprovement in student performance /提高学生成绩

○Availability of school funding/学校资金支持 OPersonal pedagogical approach/个人教学方法

○Other / 其它原因:

Q25. Which of the following do you think most contributes to the lack of multimedia use in teaching Chinese at your school? 下列哪个因素是限制您使用多媒体教学的最主要原因? (限选一项)

OSchool requirement/学校规定及要求 OMaking teaching less effective/降低教学质量

OInfluence from colleagues /同事影响 oDeficiency in student performance/学生成绩下降

oLack of school funding/学校资金匮乏 OPersonal pedagogical approach / 个人教学方法 
○Other /其它原因:

Q26. Have you ever collaborated with teachers of other subjects in the use of multimedia in teaching?

您是否曾跟其它科目的老师一起合作使用多媒体教学?

$\circ$ Yes / 是 (How have you collaborated /你们是如何进行合作: )

$\circ$ No / 不 (Reason /原因:

Q27. Are there any online resources or websites you think are the most useful in teaching Chinese? (Please specify) 您认为 哪些网络资源或网站对您进行汉语教学最有帮助? 请列举。

Q28. If applicable, what problems have you encountered when using multimedia in teaching Chinese in class?

如果您使用多媒体进行课堂教学，您在使用过程中有什么困难？

Q29. Do you have other suggestions or comments?/您是否有其它意见或建议?

I really appreciate your concerted effort in filling out the survey that is part of the research project for my Master's thesis. This research project guarantees respondent confidentiality; the survey data will be integrated and analyzed in a form that will make it impossible to determine the identity of the individual responses. The data that will be used and the outcome will all be used solely for the subject at hand, and will not be reported outside the research project. The original survey forms will be disposed at the end of the research project. Thank you!

感谢您志愿接受并耐心填写此问卷, 此调研为本人做研究生论文所用。我将用以下方式保护您提供的资料: 我会将问卷答案键入电脑后, 把您的姓名改成编号, 再将纸本问卷予以碎纸销毁。本调查研究结果将以综合结 论的方式公布，并不会包括可辨识的个人资料。谢谢！

\section{ACKNOWLEDGEMENTS}

The author wishes to thank Dr. David Hemphill, Dr. Ming-yeh Lee, Dr. Wen-Chao Li, Dr. Hellen Hyun, Professor Hui Zhang, Professor Zhong-shan Li for guidance and comments throughout this field study. The author also appreciates Wilson Tam, Juene Turner, Mary Leong, Peggy Kao, Bih-Yuan Yang, Juan Li, and Hesper Wilson for their valuable time and effort in assisting with this study.

\section{REFERENCES}

[1] Al-Seghayer, K. (2001). The effect of multimedia annotation modes on L2 vocabulary acquisition: A comparative study. Language Learning \& Technology, 5(1), 202-232.

[2] Al-Senaidi, S., Lin, L., \& Poirot, J. (2009). Barriers to adopting technology for teaching and learning in Oman. Computers \& Education, 53(3), 575-590.

[3] American Council on the Teaching of Foreign Languages. (2012a, December 11). Foreign language enrollments in K-12 public schools: Are students ready for a global society? [Executive Summary]. Retrieved August 1, 2014 from http://www.actfl.org/sites/default/files/pdfs/ReportSummary2011.pdf.

[4] Asia Society \& China Institute. (2009). New York task force: Report on Chinese language and culture initiatives. Retrieved August 1, 2014 from http://www.chinainstitute.org/cimain/wpcontent/themes/chinainstitute/pdfs/education/NYTF_final.pdf.

[5] Aziz, S., Shamim, M., Aziz, M. F., \& Avais, P. (2013). The impact of texting/SMS language on academic writing of studentswhat do we need to panic about?. Elixir Linguistics and Translation, 55(2013), 12884-12890.

[6] Bill \& Melinda Gates Foundation. (2012). Innovation in education: Technology \& effective teaching in the U.S. Seattle, WA: Bill \& Melinda Gates Foundation.

[7] Bungum, B. (2006). Transferring and transforming technology education: A study of Norwegian teachers' perceptions of ideas from design \& technology. International Journal of Technology and Design Education, 16(1), 31-52.

[8] Canning-Wilson, C., \& Wallace, J. (2000). Practical aspects of using video in the foreign language classroom. The Internet TESL Journal, 6(11), 1-6.

[9] ChanLin, L. J., Hong, J. C., Horng, J. S., Chang, S. H., \& Chu, H. C. (2006). Factors influencing technology integration in teaching: A Taiwanese perspective. Innovations in Education and Teaching International, 43(1), 57-68.

[10] Chen, Q. (2014). Bibliometric analysis on the study of education informatization. In Frontier and future development of information technology in medicine and education (pp. 869-877). Springer Netherlands.

[11] Chun, D. M., \& Plass, J. L. (1996). Effects of multimedia annotations on vocabulary acquisition. The Modern Language Journal, 80(2), 183-198.

[12] Clarke, L., \& Heaney, P. (2003). Author On - Line: using asynchronous computer conferencing to support literacy. British Journal of Educational Technology, 34(1), 57-66.

[13] Common Sense Media. (2012). Children, teens, and entertainment media: the view from the classroom. San Francisco, CA: Common Sense Media.

[14] Corbeil, G. (2007). Can PowerPoint presentations effectively replace textbooks and blackboards for teaching grammar? Do students find them an effective learning tool?. CALICO Journal, 24(3), 631-656. 
[15] Draper, J. B., \& Hicks, J. H. (2002). Foreign language enrollments in public secondary schools, Fall 2000. U.S. Department of Education, Office of Educational Research and Improvement, Educational Resources Information Center.

[16] Foster, W., \& Goodman, S. E. (2000). The diffusion of the Internet in China.

[17] Fang, X., \& Warschauer, M. (2004). Technology and curricular reform in China: A case study. TesOL Quarterly, 38(2), 301323.

[18] Furman, N., Goldberg, D., \& Lusin, N. (2010). Enrollments in languages other than English in United States institutions of higher education, Fall 2009. New York, NY: Modern Language Association. Retrieved August 1, 2014 from http://files.eric.ed.gov/fulltext/ED513861.pdf.

[19] Gray, L., Thomas, N., and Lewis, L. (2010a). Educational technology in U.S. public schools: Fall 2008 (NCES 2010-034). U.S. Department of Education, National Center for Education Statistics. Washington, DC: U.S. Government Printing Office.

[20] Gray, L., Thomas, N., and Lewis, L. (2010b). Teachers' use of educational technology in U.S. public schools: 2009 (NCES 2010-040). National Center for Education Statistics, Institute of Education Sciences, U.S. Department of Education. Washington, DC.

[21] Harknett, R. J., \& Cobane, C. T. (1997). Introducing instructional technology to international relations. Political Science and Politics, 30, 496-500.

[22] Ismail, S., Almekhlafi, A., \& Al-Mekhlafy, M. (2010). Teachers' perceptions of the use of technology in teaching languages in United Arab Emirates' schools. International Journal for Research in Education, 27(1), 37-56.

[23] Kost, C. R., Foss, P., \& Lenzini, J. J. (1999). Textual and pictorial glosses: Effectiveness on incidental vocabulary growth when reading in a foreign language. Foreign Language Annals, 32(1), 89-97.

[24] Lowry, R. B. (1999). Electronic presentation of lectures - effect upon student performance. University Chemistry Education, $3(1), 18-21$.

[25] Mackey, A., \& Gass, S. M. (2005). Second language research, methodology and design. TESL-EJ, 9(3), 92.

[26] McKinnon, D. H., Patrick Nolan, C. J., \& Sinclair, K. E. (2000). A longitudinal study of student attitudes toward computers: Resolving an attitude decay paradox. Journal of Research on Computing in Education, 32(3), 325-335.

[27] Pew Research Center. (2012, November 1). How teens do research in the digital world. Retrieved August 1, 2014 from http://www.pewinternet.org/2012/11/01/how-teens-do-research-in-the-digital-world/.

[28] Project Tomorrow. (2014, June). The new digital learning playbook, advancing college and career ready skill development in K-12 schools. Retrieved August 1, 2014 from http://www.tomorrow.org/speakup/pdfs/SU13Educatorreport_WEB.pdf.

[29] Rankin, S. L. (2010). The impact of text messaging language shortcuts on developmental students' formal writing skills. ProQuest LLC.

[30] Richtel, M. (2012, November 1). For better or worse, technology use alters learning styles, teachers say. New York Times, A18 Retrieved August 1, 2014 from http://www.nytimes.com/2012/11/01/education/technology-is-changing-how-students-learnteachers-say.html?pagewanted=all.

[31] Rubin, J. (1990). How learner strategies can inform language teaching. Language Use, Language Teaching and Curriculum, 270-284.

[32] Salem, A. (2013). The impact of technology (BBM and WhatsApp applications) on English linguistics in Kuwait. International Journal of Applied Linguistics \& English Literature, 2(4), 64-69. 10.7575/aiac.ijalel.v.2n.4p.64.

[33] Timuçin, M. (2006). Implementing CALL in an EFL context. ELT Journal, 60(3), 262-271.

[34] Williams, Z. (2013). "The Use of Multimedia Material in Teaching Chinese as a Second Language and Pedagogical Implications". Masters Theses 1911 - February 2014. 1016. University of Massachusetts, Amhearst.

[35] Yang, S. C., \& Huang, Y. F. (2008). A study of high school English teachers' behavior, concerns and beliefs in integrating information technology into English instruction. Computers in Human Behavior, 24(3), 1085-1103.

[36] Yeh, Y., \& Wang, C. W. (2003). Effects of multimedia vocabulary annotations and learning styles on vocabulary learning. Calico Journal, 21(1), 131-144.

Siyi Gao, Assistant Professor at the Defense Language Institute Foreign Language Center, Monterey, CA, USA. Her research interests include teacher professional development, integrating technology in language teaching, memory retention, and curriculum development. 